\section{The Virus Collector}

SARS. Flu. HIV. Poxviruses. Dutch virologist Albert Osterhaus is always where the action is. How many viruses can one person keep track of?

Rotterdam, Netherlands-It was the study the world was waiting for. By early April, everybody suspected that a newly discovered coronavirus was the cause of severe acute respiratory syndrome (SARS). But to prove it, researchers had to infect animals with the virus, show that they got sick, and show that their bodies began producing the virus. In other words, they had to fulfill Koch's postulates.

Enter Albert Osterhaus, 54, a virologist at Erasmus University Medical Center in Rotterdam, the Netherlands. He had just what was needed: the equipment and people to in-

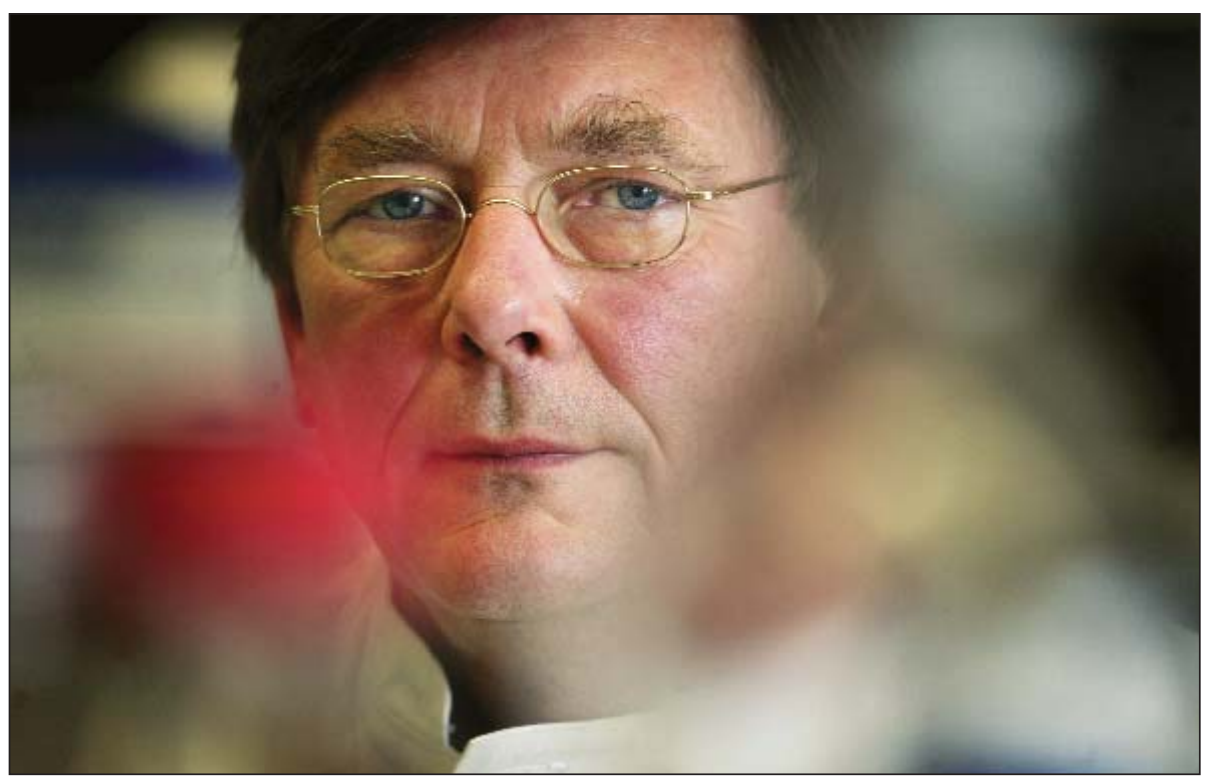

Dutch touch. Albert Osterhaus has a knack for discovering new viruses.

fect monkeys with the virus under strict biosafety conditions and then dissect the animals to study their internal organs. The experiment started on 20 March; 3 weeks later, Osterhaus flew to Geneva to announce the results in a press conference along with Klaus Stöhr, the World Health Organization (WHO) virologist who coordinates the international SARS effort. And once again, fellow virologists were left scratching their heads and wondering: How does he do it?

Over the past 2 decades, Osterhaus has played a key role in the discovery of more than a dozen pathogenic human and animal viruses. Colleagues describe him as an ambitious, alert, and tireless workaholic with a knack for being at the right place at the right time. "He just smells viruses," says his co-worker Guus Rimmelzwaan. Osterhaus's role in the SARS story is especially remarkable, others say, because he's also at the epicenter of efforts to control a devastating flu outbreak among poultry in the Netherlands.

Besides SARS and flu, his scientific work - a PubMed search last week turned up 498 papers-covers HIV, measles, rubella, hepatitis, herpes, hantavirus, and hemorrhagic fevers, among others. And then there are the viral diseases in rodents, African wild dogs, seals, and dolphins.

"It's just completely astonishing to me," says epidemiologist Roel Coutinho, director of the Municipal Health Service in Amsterdam. "He has only one head and two hands, right?"

His broad interests and fundraising prowess have made Osterhaus, who runs a 100-person research and diagnostic lab, an oddity in the small-scale and perennially cash-strapped Dutch research scene. In many ways, his lab resembles less an academic group than a miniature version of the U.S. Centers for Disease Control and Prevention (CDC) in Atlanta (except that CDC doesn't do Serengeti lions). Some say his strength is also his weakness - that Osterhaus is always skimming the field and never digs in deep. Still, "he has consistently done very good work," says CDC's leading SARS scientist, Larry Anderson. "You have to admire him for his incredible energy and the things he gets done," adds Peter Rottier of Utrecht University in the Netherlands.

The SARS monkey study was a case in point - and vintage Osterhaus, some say. Once he had received the virus from Hong Kong virologist Malik Peiris, Osterhaus decided there was no time to consult an animal ethics panel about the trial, as required by Dutch law. Instead, the director of his university's animal lab got a top official at the Dutch health department to sign off on the study, on the condition that the researchers seek approval after the fact. The move rankled animal-rights activists and a member of parliament; health secretary Clémence Ross-van Dorp later conceded it had not been handled adroitly.

But Osterhaus says he would do it again. "At that point, we were still having lengthy discussions in the WHO network about what caused SARS," he says. "This really needed to be done as fast as possible." He concedes he also wanted to beat rivals to the finish. He did: Nature published his paper-his 499th - about the monkey study on 15 May.

\section{Credit fights}

"Good morning! Anybody in yet? Is everybody still sleeping?" It's 9:15 on a sunny Wednesday morning, and Osterhaus, wearing a red shirt and his trademark black vest, is giving a whirlwind tour of his lab. The members of his staff look tanned but a little groggy: They just returned from a 6-day retreat in Curaçao that he held partly to reward them for their hard work. (Osterhaus joined them, but just for 2 days before he rushed back to work.) Occupying the entire 17th floor of a medical faculty building, the rooms offer breathtaking $360^{\circ}$ views of Rotterdam's skyline. But Osterhaus doesn't care for the panorama: He hails from Rotterdam's eternal rival, Amsterdam.

Still, this port city's industrious reputation-it's said that shirts are sold in Rotterdam with the sleeves rolled up - seems to fit the lab perfectly. Ever since WHO's Stöhr invited Osterhaus to join the worldwide hunt for the SARS virus in early March, the lab has been a madhouse, says Ron Fouchier, the lead SARS researcher. Behind the united front of the WHO network, competition has been stiff, with researchers often working deep into the night. Osterhaus is a demanding lab chief, "but he works harder than anybody else," Rimmelzwaan says.

Stöhr says he asked Osterhaus to join the WHO group because he's an "excellent scientist." In addition to having the vital 
ability to do monkey experiments, another big plus was that in 2001 Osterhaus had discovered the human metapneumovirus, which causes respiratory infections in children and was an early suspect in the SARS outbreak. Osterhaus helped other labs test suspected SARS patients for the virus, which today is believed to be at best an accomplice of the coronavirus. Although mass-scale DNA sequencing is not its forte, his lab also determined the sequence of several chunks of the coronavirus genome, helping CDC complete its version of the genome and earning Osterhaus and Fouchier co-authorships on a paper published online by Science 3 weeks ago (www.sciencemag.org/cgi/content/ abstract/1085952).

Just as SARS started its rampage, the vast Dutch poultry sector was struck by avian influenza. Again, Osterhaus was well positioned. In early 1997, his lab received a tissue sample from a 3-year-old boy in Hong Kong who had died from a mysterious pneumonia. Well ahead of the four global flu reference labs WHO had consulted, Osterhaus's group discovered that the virus belonged to an avian influenza strain called H5N1. At first, colleagues were skeptical, Fouchier recalls; avian influenza viruses weren't thought to cause severe disease in humans, let alone death. But other labs confirmed the finding, and later that year, 17 more people in Hong Kong were infected with H5N1 and five died. The city's entire chicken population was destroyed to quell the outbreak.

Today the Netherlands is struggling with a different strain, called H7N7, which has caused eye infections in more than 80 people and killed one veterinarian (Science, 2 May, p. 718). Flu experts worry that if the avian virus recombines with a human flu virus, it could create a lethal new strain. Along with the four reference labs, Osterhaus is working on vaccines and diagnostic tests against H7N7. "This is a dress rehearsal for a real pandemic," Osterhaus says.

The twin outbreak has made Osterhaus a familiar face in his home country. A member of countless national and international panels, he seldom declines requests for interviews and has been on television at least 20 times since early March. "Ab loves to hear himself talk," says Fouchier, "but he does it really well."

Colleagues say Osterhaus's energy and personality are an asset to the bustling labbut they can be a problem, too. Younger scientists have trouble establishing themselves under his towering ego. Osterhaus, for instance, has long insisted on being last author - a position indicating seniority - on many papers leaving his lab. His associates don't dispute his involvement in much of the work, but they need the credit. "We've fought over that, and pretty hard, too," Fouchier says. Several compromises have been worked out; several senior researchers in his lab now grant Osterhaus last authorship on every other paper he played a role in.

Rob Gruters, who does most of the lab's work on HIV, compares his boss to Eddy Merckx, a legendary Belgian bicyclist nicknamed "The Cannibal" because his searing desire to win eclipsed a generation of his colleagues. "Ab wants it all," says Gruters. Still, he says, Osterhaus is fun to work with. He appreciates his staff members' ideas and gives them freedom to pursue their interestseven if they're offbeat.

\section{Deeper questions}

High on a wall in Osterhaus's office hangs a poster with a picture of a sad-looking cat whose belly is the size of a soccer ball. It's suffering from feline infectious peritonitis, a fatal condition caused by a coronavirus. Osterhaus, a veterinarian by training, did his Ph.D. on the virus in the late 1970s - and never worked on coronaviruses again until SARS showed up.

But animal diseases have continued to fascinate him. As a researcher at the $\mathrm{Na}$ tional Institute of Public Health and the Environment in Bilthoven, which he joined in 1978, he discovered a new herpesvirus that caused a small outbreak among seals in the Dutch Wadden sea in 1984. When the animals started dying en masse across northern Europe 4 years later, he was on the case again. At the time, many believed pollution was killing the mammals, but Osterhaus showed that a canine distemper-like virus did them in.

Wildlife viruses are still one of his passions. Many new human diseases come from animals, he says-including, most likely, SARS. His staff is currently stalking a mysterious agent that's killing red squirrels in the Netherlands.

At Erasmus University, Osterhaus has free rein to do whatever he likes. Tapping into the biodefense rage, he's started working on poxviruses. With support from the U.S. National Institute of Allergy and Infectious Diseases, Gruters is working to develop an
HIV vaccine. Osterhaus has two companies to commercialize his findings; most of the revenues are cycled back into the lab, he says, where they help pay for the wildlife studies or, for that matter, last month's Caribbean junket. Last year, he licensed the worldwide rights to develop vaccines and antibodies to the human metapneumovirus to MedImmune, a biotech in Gaithersburg, Maryland. The down payment alone reeled in $\$ 10$ million-most of which goes to the university.

And yet he's not satisfied. Osterhaus missed out on several recently discovered fatal viruses - such as the Nipah virus from Malaysia-because he doesn't have a biosafety level 4 lab, the multimillion-dollar pressurecontrolled facilities where scientists work in space suits. He wants the medical center to help him build one, and with all the money he's bringing in, he reckons they owe him. "I simply need it," he says. "Otherwise I can't move ahead.'

Some colleagues, especially in the small world of Dutch virology, charge that Osterhaus is a scientific stamp collector. But others say such complaints are motivated by professional envy. "I think he's the best and most fun researcher we have in Holland," says virologist Jaap Goudsmit, chief scientific officer of Crucell, a Dutch biotech.

In any case, the criticism doesn't seem to bother Osterhaus. He can't imagine spending his career on just a few viruses - it would be boring, he says. Besides, there are deeper questions that drive him: Where do new diseases come from? What causes them to pop up at a certain place and time? And how can they be stopped? "Maybe I should sit down more to write about that," he says. "Often there's just not enough time."

And then he has to dash off. He needs to prepare for a major grant review meeting the next day and has to be in a TV studio at 6 p.m. to talk about SARS. And, of course, there are new viruses to hunt down. The 500th paper is just weeks way.

-MARTIN ENSERINK 